\title{
How Do Santri, Local Wisdom, And Digital Transformation Affect Community Empowerment?
}

\author{
Aang Kunaifi ${ }^{1}$, Khusnul Fikriyah ${ }^{2}$, Dewi Aliyah ${ }^{3}$ \\ ${ }^{13}$ Institut Agama Islam Al-Khairat Pamekasan, Jawa Timur, Indonesia \\ ${ }^{2}$ Universitas Negeri Surabaya, Jawa Timur Indonesia \\ Correspondent: angkunaifi@alkhairat.ac.id ${ }^{1}$, khusnulfikriyah@,unesa.ac.id ${ }^{2}$, \\ daliyah752@gmail.com ${ }^{3}$
}

\author{
Received : August 08, 2021 \\ Accepted : August 25, 2021 \\ Published : October 31, 2021
}

Citation: Kunaifi, A., Fikriyah, K., Aliyah, D. (2021). How Do Santri, Local Wisdom, And Digital Transformation Affect Community Empowerment?. Ilomata International Journal of Social Science, 2(4), 246-257. https://doi.org/10.52728/ijss.v2i4.359

\begin{abstract}
Santri is an unique person in a various economic activities. In the mix of local wisdom that is thick with spiritual values and wrapped in the dynamics of the use of digital technology, students are seen as having a real influence in realizing community empowerment in the economic field. This article aims to describe the role of santri through local wisdom and the use of digital technology in creating community empowerment. To get accurate and up-to-date information, observations and collect information has done by interviewed to santri about their strategies in dealing with economic problems in the regency as well as tips on utilizing digital technology. Furthermore, the information is checked with primary sources in the form of community members to measure the effectiveness of the role of the santri. The analysis and discussion of the data was carried out qualitatively with the phenomenological approach of the Madurese community. The research findings in this article show that there is a collaboration of the attitude and mentality of students in the midst of society with personal capital of independence, honesty, and work ethic. In terms of using digital technology, they are also able to adapt quickly and precisely. Thus, this research is expected to be able to provide a complete and accurate description of the existence and role of santri in creating community empowerment in the economic field, so that regulatory and policy makers can determine priorities in regional and national development.
\end{abstract}

Keywords: santri, Local Wisdom, Digital Technology, Social Welfare

\section{INTRODUCTION}

According to data compiled by BPS in 2020, the population of East Java reaches 40.6 million people (about 15\%), with various cultures. Sutarto stated that the East Java region was grouped into ten cultural areas or what could be termed tlatah. The cultural area (tlatah) is divided into four large courts (Mataraman, Arek, Madura Island, and Pandalungan), and six small courts (Java Panoragan, Osing, Tengger, Madura Bawean, Madura Kangean, and Samin). It is this utterance 
How Do Santri, Local Wisdom, And Digital Transformation Affect Community Empowerment? Kunaifi, Fikriyah, Aliyah

that then distinguishes the characteristics of the community based on their area of residence in East Java. (Ran et al., 2020; Triatmanto et al., 2021)

The cultural area in East Java with the largest population is in the Mataraman district, which is 34.62 percent, then the Arek tribe is 30.86 percent, the Pandalungan district is 24.67 percent and the Madura community is 9.85 percent. In this cultural area, there are also business activities that are wrapped in local wisdom that has been practiced by the community, as well as economic activities based on sharia. (Berghuis et al., 2021; Pratiwi et al., 2021)

In the economic sector in many villages, most of them are inhabited by students through entrepreneurial activities in various economic sectors in the form of traditional and nontraditional markets. All are managed independently by students or the community, most of whom come from a pesantren education background. So that in reality, the economic empowerment of rural communities is carried out by people who have an ethos and high productivity from a pesantren background. The number of students continues to grow, and this has enormous potential if properly managed in relation to efforts to build economic independence and create social welfare. Therefore, it is important to empower the entrepreneurial potential of students so that students are not only competent in the field of religion (tafaqquh fiddin), but can also be economically independent. (Collazos \& Mora, 2020; Patriadi et al., 2015)

Santri have well-established moral or spiritual provisions, the main provisions are honesty, social solidarity, and independence, in line with the entrepreneurship program. In the spiritual aspect they have recognized prayer as the main weapon in doing all endeavors. Like pearls that have not been honed, students have great potential as part of society. One thing that cannot be denied is their existence as a leader who is used as a reference for the community. Its individual role is an extension of the mission of the pesantren where students study religion, related to that strategic role, the message of independence will reach the wider community. (Thohir et al., 2021; Yusuf \& Wekke, 2015)

In the context of simple problems, community economy is a "survival" strategy developed by poor people, both in cities and villages. Improving welfare, the economy is the goal in community empowerment activities. Economics can be interpreted as an effort to manage the household. The goal is to meet the needs of life through three main activities, namely: production, distribution, and consumption. Production is the first stage to fulfill others economic activities, in particular to make community empowerment than creat a welfare. Fulfillment of life with limited resources is closely related to efforts to increase prosperity and welfare. Community empowerment could be design by developing village life, and also by industrial manufacturing. Some regencies that have an natural resources need an access to exploringor mining. In that case, community empowerment created by partnership between traditional miners and enterprises. (Chen et al., 2021; Idham, 2018)

The presence of digital technology will certainly help accelerate community empowerment efforts in the economic field. Through the transformation of digital technology into community interaction and its proper use, it will increase the income factor of the community and become an opportunity for the emergence of economic activities that further enhance community empowerment. Digitalization is one of the catalysts in increasing economic benefits in various community economic activities such as micro and small businesses. Through the process of 
offering, marketing, and selling using digital media, it is hoped that they will get the opportunity to offer to 150 million potential buyers. In fact, mobile, analytics, social media, sensors, and cloud computing have already fundamentally changed the entire business landscape as we know it $\square$ including your industry. Successful transformation in a clear, two-part framework: where to invest in digital capabilities, and how to lead the transformation. Of course, the cost is also small, aka much more efficient than offers and promotions on television, electronic media, and manual print media. Therefore, it is very important and urgent to explore and describe the role of santri as a component of society in creating empowerment in the economic field. (Hadiono \& Santi, 2020; Mergel et al., 2019)

\section{METHOD}

This study uses a qualitative approach with a phenomenological strategy. Data is collected through information from primary sources, namely the community who are students or alumni of Islamic boarding schools. To maintain the comprehensiveness of the data, crosschecks were carried out with other sources, namely primary sources from community leaders and secondary sources from online news. This form of phenomenological research is similar to similar research on efforts to optimize the role of a laboratory in educating the academic community about product literacy of Islamic financial institutions. Also about the literacy level of the academic community in an area towards Islamic financial industry products. The information is analyzed with various theories regarding empowerment, local wisdom, and the social life of students. Furthermore, it is described about the role and influence of students, local wisdom and the transformation of digital technology in community empowerment in the economic field.

\section{RESULT AND DISCUSSION}

\section{Social and Economic Potential of Santri}

The term santri actually has two connotations or meanings. The first is those who obey the orders of the Islamic religion. In a sense, those who are referred to as the "abangan" group are influenced by pre-Islamic Javanese cultural values, especially those from Hindu and Buddhist mysticism. Second, santri are those who are currently demanding education in Islamic boarding schools. Both are different even though they both study Islam. According to the General Indonesian Dictionary (KBBI), the composition of W.J.S. Poerwadarminta, gave an understanding that the word santri means: People who study Islamic studies (by going to Islamic boarding schools, etc.), are also people who worship sincerely. Nowadays, the term santriwan (male) and santriwati (female) are commonly used. Currently, the tradition of studying religion in the style of santri is starting to be adapted by the city community. This is shown by the enthusiasm of various masca recitations which are carried out colossally and exclusively in small groups. In this context, students who come from pesantren actually have an important role to share their education and experiences while at the pesantren.

According to Zamakhsari Dhofier, santri are an important element in a pesantren institution. There are 2 (two) groups of students, namely: Santri mukim, namely those who come from faraway areas and live in pesantren groups. There are also Santri bats, namely those who come from the villages surrounding the pesantren, and usually do not live in the pesantren. To take lessons at the pesantren they go back and forth (nglaju) from where they live. A santri goes and stays in a pesantren for various reasons, namely: first, he wants to study other books that discuss 
Islam in more depth under the guidance of the kyai who leads the pesantren, second, he wants to gain experience of pesantren life, both in the field of teaching, organization and relations with well-known Islamic boarding schools, thirdly, he wants to concentrate his studies at pesantren without being preoccupied with daily activities at his family home. The author needs to report the results in sufficient detail so that the reader can see which statistical analysis was conducted and why, and later to justify the conclusions.

Characteristics of students in economic activities include: Open opportunities to develop businesses, create a work atmosphere in accordance with their own desired ideals. Ability to actualize and demonstrate the full potential of intelligence, creativity, skills and pioneering. Precise in determining steps and actions in accordance with the mind, talent, will and ideals. Opportunity to obtain maximum benefits and benefits. Impact on community empowerment with concrete efforts and results. Provide opportunities to become professional entrepreneurs, by having employees in accordance with the needs and progress of the business. Can manage and determine their own working time, not bound by various work rules and regulations. As well as creating social status and self-image in the community through the transfer of knowledge and experience in society, a culture of friendship and building relationships without gaps.

The unique character of students who always maintain the values of Islamic teachings will further enrich their potential in society. The community assumes that the success of the santri in his business and obtaining profits so that having adequate assets will benefit others, so he is respected by the community not because of his wealth, but because of his skills and honesty, as well as his contribution to the welfare of society.

\section{Local Wisdom}

Local culture (also often called regional culture) is a term that is usually used to distinguish a culture, because culture can be interpreted as national culture (Indonesia) and global culture. Local culture is a culture that is owned and carried out by people in certain locations or regions, of course this culture is different from the culture owned by people in other places. Regional culture is "a value system adopted by a particular community/community group in the region, which is believed to be able to fulfill the expectations of its citizens and in it there are values, attitudes, and procedures of the community which are believed to be able to fulfill the lives of its citizens".

Local wisdom is the cultural wealth of certain areas that have moral values, knowledge, and as a source of contextual knowledge. This value is born from certain communities in various kinds of customary rules which are used as unwritten norms which until now have been adhered to together. Local wisdom can be synonymous with the culture of a region, where etymologically its meaning can be contradicted by the term globalization. Regional culture and nationalism are paradoxes in an increasingly global era, business competition is getting tougher, especially to make connections (market penetration). A contradictory value means that globalization will be accepted by a community or society if it is not against the culture or at least globalization must be able to accommodate the culture in a society. It must be admitted, that globalization is a trend and a necessity that will be carried out by marketers, considering the production potential and intense competition.

Contextualization of local wisdom in community empowerment can be positioned as a challenge or obstacle. Sometimes a very strong culture actually becomes resistant to new ideas and ideas. Thus, it is not easy for anyone, such as students who have been around for a long time and 
interact a lot with heterogeneous communities and then bring a new idea in a society, usually will get obstacles. However, an open culture will easily accommodate new ideas which will then become a catalyst in the community empowerment process. Local wisdom could be a commercial opportunity, in case many products natural destination has interested and unique. In fact, the position of the santri is able to condition the challenge into an opportunity and even a carrying capacity.

\section{Digital Transformation}

The transformation of digital technology has created a new communication pattern called new wave technology, namely information technology that develops so quickly and is multifunctional, from just a medium to convey things to each other to become a medium for discussion, supply, demand and deals that do not only connect parties. related, but also involves the participation of other people in giving other opinions and expressing their experiences as consumers of a product. The availability of digital technology has created collaborative marketing as a seamless and seemingly seamless situation. There are no secrets and information that can be hidden anymore, because everyone has been given access. This situation is supported by internet technology, cellular telephones and open source which gave birth to several social media that are rife and very familiar in the community. Some of the existing social media can be categorized into two parts, namely; expressive social media and collaborative social media.

Digital transformation is a necessity to survive and advance in the era of industry 4.0, as evidenced during the pandemic in the BPS report in July 2020, community activities at home (WFH) increased by 17\%. Kompas, based on the results of a May 2020 survey, stated that 8 out of 10 people in Indonesia are familiar with using social media. Even the digital world market has reached 150 million people with a potential transaction of around $1,800 \mathrm{~T}$ by 2025 . That is, by utilizing digital media as a means of offering products or services, promotional media, and transaction media, business actors have the opportunity to offer 150 million potential buyers. . Therefore, digital technology can be a supporting force for efforts to increase or empower the community's economy. Digital transformation can be used as a means of accelerating community economic development, both in the field of small and medium enterprises and industry. In addition, the discovery of digital technology and its transformation will make resources efficient, especially as an alternative to non-renewable energy. Therefore, in empowering the community's economy, digital transformation is very important, provided that it is used effectively. Furthermore, it will accelerate the creation of economic development and prosperity.

\section{Community Economic Empowerment}

In the context of simple problems, community economy is a "survival" strategy developed by poor people, both in cities and villages. Improving welfare, the economy is an activity in community empowerment. Economics can be interpreted as an effort to manage the household. The goal is to meet the needs of life through three main activities, namely: production, distribution, and consumption. Fulfillment of life with limited resources is closely related to efforts to increase prosperity and welfare. The basic theory of community empowerment in economic activities in terms of production, distribution, and consumption will not work effectively without social capital. The social environment and social subjects are the elements of actors who will move the commodity starting from the provision of production raw materials to the consumption stage. It takes social creativity and a strong role to utilize the available resources. 
Production, distribution and consumption are a series of activities that take place continuously and are often referred to as continuous processes. This process runs naturally in line with the development of society in the social, economic, cultural and political fields. Economically, natural processes show that those who produce (production) must be enjoyed (consumption), and vice versa those who enjoy must be those who produce. The three components of economic actors, namely individuals, society and the state. Each of them has a role and function in creating welfare. The three of economic actors (person, social, and government) must create an interrelation in the form of synergy. In a stricter sense, the three of them must carry out the roles that become their authority. If one of the three neglects it, it will be difficult to achieve equity and prosperity.

The three community economic activities above require contributions from all community instruments, namely in the form of households, companies, and the government. All three have responsibilities and obligations to carry out economic activities aimed at creating prosperity. The concept of empowerment can be done in the following ways:

a. Preparation in the formation of a workforce that has the passion and ethos to work. Utilize the capabilities possessed by each individual and group through certain entities. So as to avoid obstacles to the realization of prosperity and welfare of the community.

b. Optimizing the function of land as production land. Soil is the most effective production area, because it produces various kinds of plants that can be consumed by each individual human being. In another sense, the use of land for the agricultural, livestock and plantation sectors has more strategic functions than just being rented out. Because by producing land for agriculture, livestock, and plantations, it will increase food security and ensure the stability of the basic needs of the community.

c. Capital productivity as a responsibility for the excess assets of some households. Utilization of capital for the business sector will increase the product simultaneously, namely by accommodating some of the energy owned by households in a job, so that the number of individuals who work will increase purchasing power. The fatal mistake of having wealth or capital is to only use it in the financial sector such as business in the stock market and (foreign) exchange market so that it does not have a significant impact on community economic empowerment.

d. Improved skills to increase production. Skill enhancement can affect product volume and quality increase. Therefore, every individual human being is expected to continue learning, studying to acquire the soft skills and technical skills needed by the community.The author may present any significant flaws and limitations of the study, which could reduce the validity of the writing, thus raising questions from the readers (whether, or in what way), the limits in the study may have affected the results and conclusions. Limitations require a critical judgment and interpretation of the impact of their research. The author should provide the answer to the question: Is this a problem caused by an error, or in the method selected, or the validity, or something else?

Community economic empowerment implies the economic development of the majority of the Indonesian people as the main agenda of national development so that concrete steps must be taken so that the people's economic growth takes place quickly (Rintuh, dkk, 2005). Thus, community economic empowerment is an economic activity carried out by the community who independently manages whatever resources they can control, and is shown to fulfill all their basic needs and that of their families. Community economic development efforts are intended to lead 
to structural changes, namely strengthening the position and role of the village economy in the national economy. So that it is expected to improve people's lives towards a better life (Rintuh, $\mathrm{dkk}, 2005)$.

The supporting factors for the occurrence of community economic empowerment are as follows (Hutomo, 2000):

a. Human Resources. Human resource development is an important component in any economic empowerment program. For this reason, the development of human resources in the context of economic empowerment must be taken seriously. Because human resources are the most fundamental element in strengthening the economy.

b. Natural resources. Natural resources are one of the development resources that are quite important in the process of economic empowerment that can be utilized to meet needs and improve people's living standards. This natural resource has been used since antiquity from the nomadic life to the industrialization era.

c. However, there are things that need to be observed in the aspect of capital, namely, how the provision of capital does not create dependence on the community and can encourage micro, small and medium enterprises to develop in a positive direction. proceed. A fairly good way to facilitate solving capital problems for micro, small and medium enterprises is to guarantee credit at existing financial institutions, and/or provide interest subsidies on loans at financial institutions.

d. Production and marketing infrastructure. To drive productivity and business growth, production and marketing infrastructure is required. If the product is not marketed, the effort will be in vain. For this reason, another important component in community empowerment in the economic field is the availability of production and marketing infrastructure. The availability of marketing infrastructure such as transportation from the production site to the market will reduce the marketing chain and ultimately increase the acceptance of the community and micro, small and medium entrepreneurs.

Permana stated that some factors led to the success and failure of community empowerment consist of internal and external factors. Internal factors include the history of the community itself, the structure and capacity of the organization, resources, and leadership (community leadership). While external factors include the macro political social system where the community is located and the presence or absence of intermediary agencies.

5. The Role of Santri in Community Economic Empowerment

The results of the study indicate that students have various potentials that are applicable in the process and activities of community economic empowerment. The potential that includes mentality and professionalism is formed through the Islamic boarding school system that is attached for quite a long time, which is 3 to 8 years, even more. Mentality and professionalism in question are personality, skills, and leadership.

a. Personality Potential

The personality of the santri is formed through learning from the experiences of his seniors, classmates, and himself. The main personality is strong motivation. Before starting life in the pesantren environment, the students have formed and have a strong motivation to improve their mentality as a provision in living life in society.

In the pesantren environment, santri are also ready with various practical lessons regulated by the management of the pesantren, such as joining a business unit. This makes the students 
more motivated to have their own business after they graduate from the pesantren. This motivation is also obtained from their unit colleagues and seniors who always accompany them. Not only are they able to motivate themselves, but they are also able to motivate other fellow students when facing problems. This arises because of the closeness that occurs as long as they join in one unit and face various problems that exist together.

The influence of peer groups on entrepreneurial motivation was also found in other studies, namely research conducted in schools by Falck, Heblich and Luedemann which found that having an entrepreneurial peer group had a positive effect on individual entrepreneurial intentions. Entrepreneurship-based education and business management have a significant impact on students' motivation to build their own businesses (Vilten \& Alcock, 2004). A strong motivation to become an entrepreneur increases the will to become an entrepreneur, namely before joining a business unit and combined with skill training after joining a business unit in a pesantren so that it has a very strong impact on students to set up their own business. The second personality potential is discipline and independence. Besides study as students, those who join business units must carry out business unit tasks that are quite time-consuming for them. This matter make them have to be able to manage their time well because they sometimes have to work more than working hours. Like the part of the cooperative, which almost every day has to prepare and pay attention to the arrangement of available products and be disciplined in running the opening and closing hours of the cooperative. A disciplined lifestyle will be able to train the individual professionalism of a santri, and this is very much needed for an entrepreneur (Abdullah, Haddade, \& Nouruzzaman, 2020).

The next personality is sincerity, honesty and responsibility. These three characteristics are related to each other along with the experience that students get while joining a business unit. By understanding the purpose of student cooperatives, namely businesses that have the principle of not taking as much profit as possible but rather learning sincerity and how to advance the business unit. With the principle of how to give not how to take, especially when you see a lot of money being made per day, you train your senses so you don't feel like stealing it because it's not our money but the people's money. Thus a sense of responsibility and honesty is also trained. Leibenstein states that training can improve entrepreneurial skills. Obviously, not all characteristics of entrepreneurs can be trained. For most santri, learning in the world of work seems to be an important experience. Meanwhile, Valo explained that the practicum seemed to play an important role in the learning process towards professionalism. It provides them with useful ideas, gives them opportunities for self-reflection and selfassessment, strengthens their self-confidence, serves as a review of previous studies, encourages them to pursue academic studies, and offers opportunities to examine social and professional requirements. in the workplace, and assist them in planning their careers (Valo, 2000). Much of santris who have innovation, creativity, have courage and have managerial ability to resources power based on morality karimah. That was, some experts call them as santripreneur .

b. Entrepreneurship Skills

Pesantren has trained practical skills in the form of calculating quickly, compiling reports neatly and other practical skills such as t-shirt design. Most students who join certain business units will have the desire to have a similar business. Like a student who joins the photocopying and printing unit, he wants to have a business in the photocopying and printing sector. This is because he already has sufficient basic skills and abilities to start a 
similar business and business. This is in line with Wekke's findings at the Roudahtul Khuffadz Islamic Boarding School, Sorong, West Papua, where he found that students were equipped with farming skills aimed at exploring the potential and preparing students to be ready in society.

In addition to practical abilities or skills, students are also trained in manage an organization or business. This ability develops with with the experience of students being members or managers of a unit business and business in pesantren. santri learn how to be good members and also how to lead by their experiences or observations. So that students have the principle of being ready to be led and ready to lead.

Santri are also taught to be able to understand the market (consumers and distributors). With the intensive interaction they do by placing the position of students as consumers and other parties such as distributors, students are able to understand the differences in the nature and background of consumers and distributors. This certainly honed their soft skills as a student entrepreneur. The existence of the traditional market itself is considered very helpful for the needs of the village community because it has been able to serve the needs of the village community even for santri as pesantren graduates are allowed to do business and business units in traditional markets around the pesantren environment. This is done with the aim of to grow the entrepreneurial potential of students in empowerment community economy.

c. Leadership in Society

In relation to an organization or a business activity, the word leader refers to the position of a person who formally has a certain status through election, adoption, revolution, or other means. In other words, leadership refers to the behavior shown a person or many people in a group with the intention of achieving a goal. Reliable entrepreneurs can be reflected in those who are able to motivate employees, and are open to criticism and suggestions from others.

The typology of santri is a human resource who has practiced managerial and organizational. Santri have received provisions and best practice regarding integrity as a person who is ready to be led, as well as a leadership spirit and ready to lead the community. A very strong social practice in the leadership of students is the culture of friendship by making visits to the community to establish harmonious social relations. This practice will provide an understanding to the community how a student figure deserves to be a leader; able to understand the state of the surrounding community. Santri will be easy to move, direct, and motivate the community in activities to move the wheels of the economy and empower the community.

Santri has a distinctive leadership that combines a rational and spiritual approach. This kind of leadership will provide high effectiveness in achieving community goals. As research on spiritual leadership in a company that is able to create a good system through human procedures and harmonization of internal relations, in the end it is able to produce a company that is not only sustainable and grow, but also has transcendental value, becoming a great company. A company that is not only beneficial for the owners and managers, but also needed by the community.

6. Acceleration of Community Empowerment through the Role of Santri, Local Wisdom, and Digital Transformation

In community empowerment, instruments are needed in the form of subjects or actors, the environment, and supporting facilities. The function of the subject is to carry out managerial activities; planning, implementation, and evaluation. The environment is a habitat for people to 
carry out all their activities. The more conducive the environment of a society, the better community empowerment will be. While the supporting facilities in empowerment activities are accessibility, infrastructure, technology, and so on which are tools to be used in order to facilitate community empowerment.

Through the characteristics of students' human resources, the potential for community empowerment in the regions in particular will run well. As part of the subject in community empowerment, students have very relevant skills and abilities, namely leadership, entrepreneurship skills and effective communication as well as independent personalities, have strong motivation, discipline, honesty, and sincerity (non-profit oriented). So the figure of the santri is the ideal figure needed to start, create, and improve community empowerment.

Local wisdom is a condition that is positioned as a currency that has two sides. Where, he can be an obstacle by the nature of his resistance to new ideas or ideas. On the other hand, it can also be a conducive atmosphere that provides full support for new ideas in community empowerment. Therefore, to create and utilize local wisdom as a good environment, massive inclusion of an idea must be carried out, and accommodate local wisdom as a form of improvisation in empowerment. This can be realized through good communication with the aim of aligning counterproductive assumptions.

Digital technology in fact also has paradoxical implications. Mistakes in utilizing it actually create a bad impression on digital technology. However, overall digital transformation is something that cannot be avoided. So the only option is to accept and use it well for the benefit of community empowerment. The typology of students who are leadership and independent will make it easier for themselves to adapt to new technology. Supported by good, reliable communication skills, it will also make it easier for businesses to explain to the public how they should adapt to digital technology.

The results of this study can be summarized in the following figure:

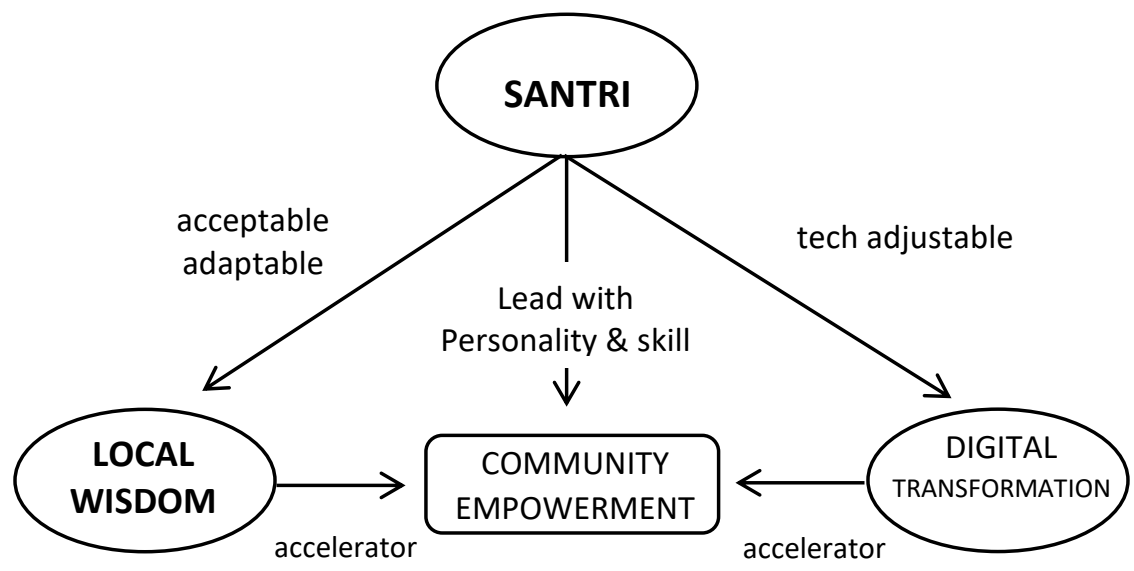

Based on the picture above, the acceleration process in creating community empowerment can be explained as follows: The first, as a resource that has been equipped with adequate personal abilities and skills, Santri has the potential to become leaders in directing the community to be productive and empowered. The second, Santri who are born from the community are easy to accept and adapt easily to the culture and way of thinking of the community. So that it is easy to provide awareness to the public while avoiding resistant cultural barriers. The third, as a 
generation of students, students tend to be friendly with technology, so that it is effective. Thus the acceleration of community empowerment will be faster and easier to realize.

\section{CONCLUSION}

Santri are ideal human resources that are relevant to be the subject of community empowerment, especially in areas or villages. The ability of students to communicate and create business opportunities, as well as trusted individuals with the characteristics of independence, discipline, honesty, and sincerity are more easily accepted by the community. Therefore, for students it will be faster and easier to interact in an environment full of local wisdom. So the assumptions of local wisdom that are counterproductive to community empowerment can be minimized. Both will be accelerated by the existence of digital technology transformation in creating community empowerment. The leadership and influence of students will make it easier for people to adapt to digital technology. These three factors will run optimally through good communication, namely communication that is integrated and has spiritual values. Therefore, Santri resources are an important potential to be improved, so that community empowerment, especially in rural areas, can be compatible with existing development in urban areas.

\section{REFERENCE}

Berghuis, H. W. K., Veldkamp, A., Adhityatama, S., Hilgen, S. L., Sutisna, I., Barianto, D. H., Pop, E. A. L., Reimann, T., Yurnaldi, D., Ekowati, D. R., Vonhof, H. B., van Kolfschoten, T., Simanjuntak, T., Schoorl, J. M., \& Joordens, J. C. A. (2021). Hominin homelands of East Java: Revised stratigraphy and landscape reconstructions for Plio-Pleistocene Trinil. Quaternary Science Reviews, 260, 106912. https://doi.org/10.1016/j.quascirev.2021.106912

Chen, Z., Ren, X., \& Zhang, Z. (2021). Cultural heritage as rural economic development: Batik production amongst China's Miao population. Journal of Rural Studies, 81, 182-193. https://doi.org/10.1016/j.jrurstud.2020.10.024

Collazos, L. E. O., \& Mora, V. A. B. (2020). Gender, violence and social resources in rural producers' economic decisions. Journal of Rural Studies, 80, 222-234. https://doi.org/10.1016/j.jrurstud.2020.09.011

Hadiono, K., \& Santi, R. C. N. (2020). Menyongsong Transformasi Digital Conference: Optimalisasi Potensi Masyarakat di Era Society 5.0 untuk Mewujudkan Indonesia Maju dan Berkarakter. In K. Hadiono (Ed.), Menyongsong Transformasi Digital (pp. 81-84). Universitas Stikubank.

https://www.researchgate.net/publication/343135526_MENYONGSONG_TRANSFOR MASI_DIGITAL

Idham, N. C. (2018). Javanese vernacular architecture and environmental synchronization based on the regional diversity of Joglo and Limasan. Frontiers of Architectural Research, 7(3), 317333. https://doi.org/10.1016/j.foar.2018.06.006

Mergel, I., Edelmann, N., \& Haug, N. (2019). Defining digital transformation: Results from expert interviews. Government Information Quarterly, 36(4), 101385. https://doi.org/10.1016/j.giq.2019.06.002

Patriadi, H. B., Bakar, M. Z. A., \& Hamat, Z. (2015). Human Security in Local Wisdom Perspective: Pesantren and its Responsibility to Protect People. Procedia Environmental Sciences, 28, 100-105. https://doi.org/10.1016/j.proenv.2015.07.015 
Pratiwi, R., Shalihat, A., Dewantisari, D., Nafisah, R. A., Yunita, Saputri, F. A., Gozali, D., Pamungkas, K., Lesmana, R., Koyama, H., \& Mutakin. (2021). Correlation study between gastronomy culture and content of selenium towards prevalence of cardiovascular and diabetes in West Java, Indonesia. Journal of Trace Elements in Medicine and Biology, 64, 126679. https://doi.org/10.1016/j.jtemb.2020.126679

Ran, W., Luan, X., Lu, Y., Wei, X., Zhang, H., Wang, K., Wang, J., Wang, X., Zhang, D., \& Saiful Islam, M. (2020). Seismic characteristics and strontium isotope ages of the Middle Miocene Ngrayong Formation in the Madura Strait Basin: Implications for the paleogeographic reconstruction of East Java. Journal of Asian Earth Sciences, 190, 104109. https://doi.org/10.1016/j.jseaes.2019.104109

Thohir, A., Supriadi, D., Mulyana, Arifin, F., \& Septiadi, M. A. (2021). The struggle of Freemasonry and Islamic ideology in the twentieth century during colonialization in Indonesia. Heliyon, 7(10), e08237. https://doi.org/10.1016/j.heliyon.2021.e08237

Triatmanto, B., Respati, H., \& Wahyuni, N. (2021). Towards an understanding of corporate image in the hospitality industry East Java, Indonesia. Heliyon, 7(3), e06404. https://doi.org/10.1016/j.heliyon.2021.e06404

Yusuf, M., \& Wekke, I. S. (2015). Active Learning on Teaching Arabic for Special Purpose in Indonesian Pesantren. Procedia - Social and Behavioral Sciences, 191, 137-141. https://doi.org/10.1016/j.sbspro.2015.04.245 